\section{Dr R. L. Knight}

DR R. L. KNIGHT, head of the Fruit Breeding Section of East Malling Research Station, died suddenly at his home on February 15, only a few weeks before he was due to retire.

Robert Knight, like many others who have made great contributions to agriculture, started his career at Wye College. There he took a Diploma in Agriculture, and went on to spend a year each at St John's College, Cambridge, and at the Imperial College of Tropical Agriculture, Trinidad. In 1929 he was recruited to the staff of the Empire Growing Corporation, as it then was, and seconded to the Sudan where, in close collaboration with the Department of Agriculture, and with colleagues of the Corporation staff in other territories, he made a great contribution to the future of both Sudan and other African territories.

At the time Sudan's future lay in the long-term success and stability of the great Gezira irrigation scheme which was to provide not only food but also cash in the form of cotton for export to Lancashire where Empiregrown cottons capable of rivalling the best American selections were needed. Existing cotton strains suffered, often disastrously, from "Black-Arm disease" due to Bacterium malvacearum. Though some genetic resistance had been recognized and used, the protection afforded was both inadequate and unreliable. Official policy based all hopes of limiting the disease on controlled rotation and on the plant sanitation procedures introduced by Massey. Nevertheless, crippling attacks occurred periodically. To the vulnerable Egyptian cottons as to the Upland cottons, Knight laboriously transferred genes and sup- porting genes for resistance which he had identified in the course of detailed research among diverse cottons, often of little or no commercial value. In so doing he was well ahead of his time, demonstrating the great ecological importance of multiple resistance factors and the possibility of combining high commercial values with resistance effective over a wide range of environmental conditions.

Knight insisted on remaining at work under the relatively primitive conditions at Shambat and when Hutchinson, already a world authority on the taxonomy and genetics of the cottons, arrived there, bringing with him the Corporation's World Collection of Cottons, Knight overbore all more cautious councils, and insisted on subjecting the collection to massive overall infection. From the results and from the belief of Nye and Hutchinson that additional resistance factors would be found among the Upland cottons, there emerged the Albar cottons and their derivatives which, by combined high resistance and commercial value, have been of such benefit in Africa. The value of a reliable cash crop that can be alternated with an acceptable food crop needs no emphasis.

Recognition of his work led to his appointment as Chief Geneticist of the Sudan Government and, in 1952, to the award of the OBE.

His chief work in the Sudan completed, Knight returned to England and in 1954 accepted an equally challenging post at East Malling. Despite the successes of Crane and Grubb, the application of genetic analysis to fruit breeding had in general progressed little beyond selection from the progeny of existing cultivars. Nevertheless, at East Malling the foundations had already been laid for the far more ambitious programmes which Knight pursued in the eighteen years following his appointment. At the National Fruit Trials at Faversham in Kent, Knight had available basic breeding material and a unique collection of cultivars of hardy fruits from all over the world. Knight inspired his team in all aspects of their work, and aroused the interest of his colleagues in pathology and entomology, while the use he made of screening techniques on the varietal collections was very similar to his use of them during his earlier studies on cotton.

His successes at East Malling are summed in the success of his team in producing, in less than 20 years, a wide range of defined genetic resources in all the tree and bush fruit crops with the exception of cherries. Progress in the planned combination of desired characters has been so substantial that clones derived from seedlings are already under test as potential replacements for existing commercial cultivars of bush fruits while the number of clones of tree fruit requiring similar tests is so large that careful advance planning is needed to ensure their speedy evaluation.

East Malling, and plant breeding as a whole, are the poorer for Knight's death. The help he gave to others, whether in the form of basic breeding material, in the editing of the scientific writings of others, or in his outstanding series of abstract volumes on the genetics of cotton, and of tree and bush fruit crops, is greatly valued. Characteristically, he was planning to use his retirement in even more generous assistance to others; his many friends, and many who will never know his name, have good cause to be grateful for his life and work.

\section{HOW TO BUY NATURE}

Volumes start in January, March, May, July, September and November, but subscriptions may begin at any time.

The direct postal price per subscription is:

12 MONTHS * (52 issues per title)

\begin{tabular}{|c|c|c|}
\hline & $\begin{array}{c}\text { Surface mail } \\
\text { UK and } \\
\text { worldwide }\end{array}$ & $\begin{array}{l}\text { U.S.A. and } \\
\text { Canada }\end{array}$ \\
\hline Nature (Friday) & $\varepsilon 14$ & $\$ 48$ \\
\hline $\begin{array}{l}\text { Nature }+ \\
\text { Nature Physical Science }\end{array}$ & $£ 24$ & $\$ 83$ \\
\hline $\begin{array}{l}\text { Nature }+ \\
\text { Nature New Biology }\end{array}$ & $£ 24$ & $\$ 83$ \\
\hline All three editions & $£ 29.50$ & $\$ 108$ \\
\hline Annual Index & \&1 & $\$ 3$ \\
\hline
\end{tabular}

- Rates for shorter periods pro rata (minimum three months) (Charge for delivery by air mail on application)
Editorial and Publishing Offices of NATURE

MACMILLAN JOURNALS LIMITED

4 LITTLE ESSEX STREET, LONDON WC2R 3LF

Telephone Nuinber : $01-8366633$. Telegrams : Phusis London WC2R 3LF Telex 262024

711 NATIONAL PRESS BUILDING WASHINGTON DC 20004

Telephone Number : 202-737 2355. Telex 64280 Subscription Department

MACMILLAN JOURNALS LIMITED

BRUNEL ROAD, BASINGSTOKE, HANTS

Telephone Number : Basingstoke 29242

American display advertisements

NATURE SCIENTIFIC PUBLICATIONS INC

711 NATIONAL PRESS BUILDING WASHINGTON DC 20004 All other advertisements

T. G. SCOTT \& SON, LIMITED

1 CLEMENT'S INN, LONDON WC2A 2ED

Telephone : 01-242 6264/01-4054743

Telegrams : Textualist London WC2A 2ED

Registered as a newspaper at the Post Office

Copyright (c) Macmillan Journals Limited, April 71972 